\title{
OLD AGE IN THE DISCOURSE OF PHILOSOPHY
}

Holyk S. V.

\begin{abstract}
But if we are not going to be immortal, it is yet desirable for man to cease living in his due time; for nature has its measure, as of all other things, so of life.

Old age is the closing act of life, as of a drama, and we ought in this to avoid utter weariness, especially if the act has been prolonged beyond its due length.
\end{abstract}

Cicero. De Senectute

\section{INTRODUCTION}

The phenomenon of old age has been the subject of philosophical inquiry for thousands of years. Deep thinkers have discussed basic notions of life, such as life course, the sense of life, the experience of aging, the fear of death, hatred and disrespect to the elderly.

Plato and other ancient thinkers emphasize on distortions of character and bodily decay as markers of ageing. However, they also agree that old age gives opportunities for "immaterial pleasures which were earlier ignored or underdeveloped," such as intellectual faculties, deep meaning of life, friendliness ${ }^{1}$.

The Middle Ages, although advocated Christian ideals, also promoted the idea of decline with the frightening dark image of old age and the isolation of the elderly which flourished even more during the period of industrialization in the $19^{\text {th }}$ century.

Our contemporary society, in the words of Baars, called the "premier philosopher of aging" ${ }^{2}$, is greatly influenced by two contradicting tendencies: firstly, "premature cultural senescing" when people usually live longer but are called old at earlier ages; and secondly, the desire to stay young but grow older $^{3}$. As it is assumed in the review of his book Aging and the Art of Living, "these paradoxes result from the contradictory desires of long life and infinite youth. Our culture produces them because it suppresses and tries to control finitude and our increasing vulnerability over time" ${ }^{4}$.

${ }^{1}$ Murphy C. F. Reflections on Old Age: A Study in Christian Humanism. Eugene, Oregon: Resource Publications, 2015. P. IX.

${ }^{2}$ Whittington F.J., Cole T.R. What's the Point of Aging? Does Philosophy Make a Difference? / The Gerontologist, 2014. Vol. 54. No. 3. P. 519.

${ }^{3}$ Baars J. Aging and the Art of Living. Baltimore: Johns Hopkins University Press, 2012. P. 84.

${ }^{4}$ Whittington F.J., Cole T.R. What's the Point of Aging? Does Philosophy Make a Difference? / The Gerontologist, 2014. Vol. 54. No. 3. P. 519. 
Present-day philosophy presents an interesting approach when "there is no explicit discussion of aging, but rather of themes or concepts that are crucial for our understanding of it" ${ }^{5}$. Drawing on these ideas, in this research the analysis is conducted to address the problematic aspects of old age and human longevity. The first part of the chapter briefly sums up the views on old age and the elderly throughout the history of philosophy, from the ancient times to modern period. The second part discusses the issues of ageing as a definitional problem, outlines the main tendencies in the verbalization of the older person and the themes of OLD AGE conceptualization in the present-day English discourse of philosophy.

\section{The philosophy of ageing: a look back}

The ontogenesis of the old age phenomenon has had a long history and is analyzed in the works of many ancient philosophers. Ancient Greeks, for instance, generally hated ageing and were afraid of it, since it represented a decline from highly praised youth and vigour. The boundaries for old age in the ancient world were also rather vague. As claimed in recent studies, e.g. Diamandopoulos (2017), the average lifespan in Classical Greece was about 25 years. Accordingly, in ancient society "the old were younger and fewer than in our own era, and there were many young people to care for them" ${ }^{6}$.

Most researchers believe that "the Classical philosophers were well aware of the common folk judgments shared by the masses of the hardships, deficiencies, and embarrassments of old age. What sets them apart is that, through their ethical, metaphysical, and epistemological commitments, they found ways to reinterpret the meaning and value of old age" ${ }^{\text {"7 }}$.

The $4^{\text {th }}$ century B.C. philosopher and physician Hippocrates, who is known as the father of medicine, also contributed to the theory of ageing. He believes that each individual, depending on their way of living, has a certain amount of innate heat or vital force that can partially be renewed. Diseases and ageing result from the disharmony and imbalance in the replenishment of the heat and lead to death. Researchers state that Hippocrates assumed this to be "a natural and normal course of things and his advice for longevity was moderation and the maintenance of daily activities" ${ }^{\text {. }}$

${ }^{5}$ Baars J. Philosophy of Aging, Time, and Finitude. / A Guide to Humanistic Studies in Aging. Eds. T.R. Cole, R. Ray \& R. Kastenbaum. Baltimore: Johns Hopkins University Press, 2010. P. 106.

${ }^{6}$ Diamandopoulos A. The ideas of Plato, Aristotle, Plutarch and Galen on the elderly / JGG, 2017. 65. P. 326.

${ }^{7}$ Audrey A. Aging in classical philosophy. / The Palgrave Handbook of the Philosophy of Aging. Ed. Geoffrey Scarre. London: Palgrave Macmillan, 2016. P. 128-129.

${ }^{8}$ Williams M. E. Growing Old in Ancient Greece and Rome. How history helps us see ourselves as we age. 2017. Available online at https://www.psychologytoday.com/us/blog/ the-art-and-science-aging-well. 
Plato's views on old age are expressed in his work The Republic, where he defines two different modes of aging - the continuity and the disengagement. Ageing as continuity is observed when the elders continue pursuing the activities they used to do when they were younger "as a means for staying robust and also for insisting that their previous efforts were not spent in vain", whereas the disengagement ageing means limiting the activity of the old, freeing them from their previous ambitions and letting them concentrate on spiritual issues ${ }^{9}$.

In The Republic, Plato views old age as an opportunity for a spiritual life when you are not distracted by the bodily issues, "for old age brings peace and freedom from all such things" 10 , "as the physical pleasures wither away, my desire for conversation and its pleasures grows" ". He also shows respect to the elderly, "I enjoy talking with the very old, for we should ask them, as we might ask those who have travelled a road that we too will probably have to follow, what kind of road it is, whether rough and difficult or smooth and easy" ${ }^{12}$. Thus, it may be assumed that in Plato's view, the elderly are social, friendly, knowledgeable and deserve respect.

Moreover, the elderly are generally seen as advisers in Ancient Greece. According to Plato, the wisdom is the property of the old and for this reason, he insists that the guardians of a wise city are likely to be old, "isn't it obvious that the rulers must be older and the ruled younger? Yes, it is"13.

Another Ancient Greek philosopher, Aristotle, displays a serious theoretical interest in old age. He believes that ageing is a natural process, and in his works On Youth, Old Age, Life and Death, and On Length and Shortness of Life discusses the issues related to this phenomenon. However, as different from Plato, for Aristotle, old age is evil, it causes decay and the older people are wicked, distrusting and inactive, many of them become annoyingly negative in old age. He suggests that middle age is the prime of life, youth is the second-best stage in life, and old age is miserable. Youth is closest to middle age in behavior, middleaged people seem to act responsibly, behave rationally, and do what they ought to do $^{14}$. Thus, Aristotle considers old age to be the worst of the three life stages.

Contemporary philosophers believe that Aristotle's characterization of the elderly character is mainly negative, that is especially clearly observed in the second book of Rhetoric where he contrasts the three types of character that accompany the three ages of life: the youthful, the elderly, and men in their prime:

${ }^{9}$ Diamandopoulos A. The ideas of Plato, Aristotle, Plutarch and Galen on the elderly / JGG, 2017. 65. P. 326.

${ }^{10}$ Plato. Complete Works. Ed.John Cooper. Indianapolis: Hackett, 1997. 329 c.

${ }^{11}$ Ibid. $328 \mathrm{~d}$.

${ }^{12}$ Ibid. 328 e.

${ }^{13}$ Ibid., 412 c.

${ }^{14}$ Cited in: Audrey A. Aging in classical philosophy / The Palgrave Handbook of the Philosophy of Aging. Ed. Geoffrey Scarre. London: Palgrave Macmillan, 2016. P. 118-119. 
The elderly character is said to be contrary to the youthful, and both are viewed as extremes while the character of men in their prime is a mean between these, possessing the valuable qualities of both and none of the vices. The elderly are, quite literally, "past their prime"(Rhetoric 1390b 7-9) ${ }^{15}$.

Viewed in a broadly negative light, old age is presented as the deterioration of the body and Aristotle regularly compares it to disease. Even more, in his Generation of Animals he calls a disease an "acquired old age" and old age, in his words, is a natural disease ${ }^{16}$.

Aristotle's theory considers heat to be an essential quality of life and it plays a central role in the explanation of the process of aging. Accordingly, everything that lives has a soul that is in the heart and cannot exist without natural heat. Life is closely interrelated with the soul and living means maintaining the heat. Researchers claim that Aristotle likened this innate heat to a fire which is maintained and provided with fuel, when the fire runs out of fuel or is put out, innate heat is also extinguished or exhausted ${ }^{17}$. A feeble flame, as in old age, is more easily extinguished than the strong flame of youth. The thinker goes on to state that the person dies of old age when the fuel is exhausted.

It is commonly agreed in philosophy, that "the bulk of his (Aristotle's) discussion addresses the material-efficient causal factors of aging, identified as the growth and decay of the lungs and corresponding exhaustion of heat in the heart" ${ }^{\prime 8}$. According to his theory of elements, all animal bodies consist of the hot and the cold, the dry and the wet. Hot and wet means being alive, while old age is dry and cold. In Aristotle's view, old age and illness are due to drying and cooling of the body.

The extraordinary ancient physician Galen in his treatise Hygiene adheres to the ideas of Aristotle and Hippocrates about the inner heat and views ageing as a gradual natural process of drying leading to the loss of vitality. Although Galen believes that a person's ageing is mostly individual, with a wide range of possible health outcomes at each stage, this stage is the innate destiny of every mortal creature $^{19}$. According to Galen, the final stage of lifespan can be subdivided into three phases of unspecified length, from active old age to senility. And he argues, in the words of contemporary researchers, that the "causes of destruction" are present "innately from the beginning", thus emphasizing on the importance of a healthy youth as the basis for a good old age ${ }^{20}$.

${ }^{15}$ Cited in: Woodcox A. Aristotle's Theory of Aging. / Cahiers des études anciennes. LV, 2018. P. 65-78.

${ }^{16}$ Ibid.

${ }^{17}$ Williams M. E. Growing Old in Ancient Greece and Rome. How history helps us see ourselves as we age. 2017.

${ }^{18}$ Woodcox A. Aristotle’s Theory of Aging. / Cahiers des études anciennes. LV, 2018. P. 65-78.

${ }^{19}$ Williams M. E. Growing Old in Ancient Greece and Rome. How history helps us see ourselves as we age. 2017.

${ }^{20}$ Burstein S.M. and Finch C. E. Longevity examined: an ancient Greek's very modern views on ageing. A 2,000-year-old view of old age. / Nature, 23.08. 2018. Vol. 560. 
Galen is the first to assume that elder care is an essential part of doctors' duties and and in the work On the preservation of health notes that ageing can be eased, delayed by prevention or managed to maximize the quality of life. He concludes that death is inevitable as "the body deteriorates of itself", but life could be prolonged ${ }^{21}$.

Previous research summarises that "the culture of Ancient Greece failed to forster a tolerant attitude towards old age, and there were few reasons for the absence of the fear of old age. In this ancient civilization people hardly survived into old age, therefore this fear was not impending”22. Although Ancient Greeks mostly disrespected the elderly and old age, older warriors, elder philosophers and statesmen were commonly well treated. In fact, the Spartans valued the wisdom of elderly citizens and set up the Gerousia, a counsel of the men in their advanced years, to control their city-state and manage their community affairs.

The Ancient Romans also displayed interest in the issues of ageing and death. Thus, Marcus Cicero assumes that old age is rarely favoured by the young, who find it unattractive, even frightening, therefore it leads to the social exclusion of the elderly, "What I find most lamentable about old age is that one feels that now one is repulsive to the young." But, as generally agreed, he also sees older people as a source of great wisdom, "States have always been ruined by young men and saved by the old" 23 .

Cicero is said to lay stress on the positive aspects of ageing and praises the activity of the elderly, their contributions to societies and achievements in literature, arts and bringing up youth ${ }^{24}$. He recognizes older men's positive features, and states they should be shown proper respect.

In a philosophical thesis, On Old Age (De Senectute), which presents the discussion of human declining years, he attempts to defend old age and outlines four main reasons why people dislike old age. Firstly, Cicero notes that many hate old age because it leads to the exclusion of the elderly and prevents them from doing their rutine activities, "Old age cuts one off from the management of affairs. Of what affairs? Of those which are managed in youth and by strength of body?But are there not affairs properly belonging to the later years of life, which may be administered by the mind, even though the body be infirm?" 25 . However, it is generally assumed that this complaint

${ }^{21}$ Burstein S.M. and Finch C. E. Longevity examined: an ancient Greek's very modern views on ageing. A 2,000-year-old view of old age. / Nature, 23.08. 2018. Vol. 560.

${ }^{22}$ Мовчан М.М. Лабіринти страху старості: проблеми і перспективи / М. М. Мовчан // Гуманітарний вісник ЗДІА. - 2013. - № 53. - С. 81.

${ }^{23}$ Williams M. E. Growing Old in Ancient Greece and Rome. How history helps us see ourselves as we age. 2017.

24 Полькина Т.М. Особенности понимания феномена старости на разных этапах психолого-философского осмысления / T. М. Полькина//Вестник Башкирского университета.- 2012. -Т. 17. - № 3. - С. 1407.

${ }^{25}$ Cicero Marcus Tullius. De Senectute (On Old Age) / Translated with an Introduction and Notes by Andrew P. Peabody. Boston: Little, Brown, and Co., 1887. 
results from a misunderstanding of what it means to be active and to pursue something actively ${ }^{26}$.

Furthermore, Cicero says that the activities performed by the aged are even more important than those of the youth:

He may not be doing what younger members of the crew are doing, but what he does is better and much more important. It is not by muscle, speed, or physical dexterity that great things are achieved, but by reflection, force of character, and judgement; in these qualities old age is usually not only not poorer, but is even richer ${ }^{27}$.

The second reason of hatred is that old age makes the body weaker. Although Cicero does not deny the loss of strength that usually accompanies old age, e.g. "Old age lacks strength, it is said", he defends this state "But strength is not demanded of old age", and goes on to explain, "To pass to the next charge against old age, I do not now feel the need of the strength of youth...any more than when a young man I felt the need of the strength of the bull or of the elephant. Such strength as a man has he should use, and whatever he does should be done in proportion to his strength" ${ }^{28}$. He also adds that older men have enough strength to advise the younger ones and share their experience and knowledge with them, "You can at least help others by your counsel; and what is more pleasant than old age surrounded by young disciples? Must we not, indeed, admit that old age has sufficient strength to teach young men, to educate them, to train them for the discharge of every duty?"29.

Thirdly, old age is said to deprive us of physical pleasures, "I come now to the third charge against old age, that, as it is alleged, it lacks the pleasures of sense". ${ }^{30}$ In defense against this accusation, Cicero adds that many pleasures are "more harmful than all things else!". Similar to Plato, he believes that such things not only prevent the elderly from intellectual pursuits, but also these pleasures may provoke outrageous behaviour: "In fine, there is no form of guilt, no atrocity of evil, to the accomplishment of which men are not driven by lust for pleasure. Debaucheries, adulteries, and all enormities of that kind have no


pleasure is not only a distraction, it is, quite possibly, the root of all evil. However, an elderly person is free from such temptation. Cicero assumes that we should be grateful to old age for preventing us from leading an immoral lifestyle, "I, indeed, for the pleasure of conversation, enjoy festive

${ }^{26}$ Audrey A. Aging in classical philosophy / The Palgrave Handbook of the Philosophy of Aging. Hrsg. Geoffrey Scarre. London: Palgrave Macmillan, 2016. P. 127.

${ }^{27}$ Cicero Marcus Tullius. De Senectute (On Old Age) / Translated with an Introduction and Notes by Andrew P. Peabody. Boston: Little, Brown, and Co., 1887. vi.

${ }^{28}$ Ibid. ix.

${ }^{29}$ Ibid.

${ }^{30}$ Ibid. xii.

${ }^{31}$ Ibid. 
entertainments, even when they begin early and end late <...> and I am heartily thankful to my advanced years for increasing my appetency for conversation, and diminishing my craving for food and drink"32. Old age is not to be blamed, rather blessed, because we could concentrate on more intellectual pursuits.

Finally, Cicero comes to the charge against old age that it is close to death, "There remains a fourth reason for deprecating old age, that it is liable to excessive solicitude and distress, because death is so near; and it certainly cannot be very far off". The fear of death, as well as fear of old age, are common themes in ancient philosophy. Cicero denies this claim, stating that death could take anyone at any age: "Youth has many more chances of death than those of my age. Young men are more liable to illnesses; they are more severely attacked by disease; they are cured with more difficulty. Thus few reach old age" ${ }^{33}$.

Another significant difference is that the elderly person, providing that he leads a virtuous life, has lived a long and good life filled with accomplishments, "There is, however, a calm and serene old age, which belongs to a life passed peacefully, purely, and gracefully...". The elderly can be free from the anxiety that their life was meaningless, they can no longer have the fear of death, "The close of other ages is definitely fixed; but old age has no fixed term, and one may fitly live in it so long as he can observe and discharge the duties of his station, and yet despise death. Old age, fearless of death, may transcend youth in courage and in fortitude" 34 .

To sum up, ancient philosophers view the value of old age as dependent on the character of the individual. Cicero admits that youthful blessings are desirable, yet he adds that the older person can retain them if he is temperate and disciplined enough not to squander such gifts. They valued this stage of life for its positive qualities, such as wisdom and honor, "I have no fault to find with old age," - a noble answer, worthy of a learned man. Unwise men, indeed, charge their vices and their faults upon old age." ${ }^{35}$ Cicero's philosophical ideas can teach how to structure your own lives in preparation for old age, "I am praising the old age that has laid its foundations in youth"36, and how to live it virtuously every day. For Cicero, receiving respect is the greatest joy you can get in your advanced years, "What pleasures of body are then to be compared with the prerogatives of authority?"37.

Seneca, another ancient Roman philosopher, compared old age to the natural disaster which crushes and sweeps everything on its way. He admits the fact

${ }^{32}$ Cicero Marcus Tullius. De Senectute (On Old Age). / Translated with an Introduction and Notes by Andrew P. Peabody. Boston: Little, Brown, and Co., 1887. xiv.

${ }^{33}$ Ibid. xix.

${ }^{34}$ Ibid. Xx.

${ }^{35}$ Ibid.

${ }^{36}$ Ibid. xvii.

${ }^{37}$ Ibid. 
that old age leads to deterioration of the body. In his Letter from a Stoic, he writes, "I am now afraid that I have left old age behind me. For some other word would now apply to my years, or at any rate to my body; since old age means a time of life that is weary rather than crushed"38. Thus, he is perfectly aware of all the threats and horrors, accompanying ageing.

Seneca, even being in his last years, feels that one should be thankful to his age for the clarity of the mind, even if the body is declining, "I feel that age has done no damage to my mind, though I feel its effects on my constitution. <...> Only my vices, and the outward aids to these vices, have reached senility; my mind is strong and rejoices that it has but slight connexion with the body"39.

Seneca believes that we should accept the fact of ageing. In fact, he considers that old age should be valued as the grand finale that ends the play of one's life, since it gives pleasure, you only need to know how to use it:

"Fruits are most welcome when almost over; youth is most charming at its close; the last drink delights the toper, the glass which souses him and puts the finishing touch on his drunkenness. Each pleasure reserves to the end the greatest delights which it contains. Life is most delightful when it is on the downward slope, but has not yet reached the abrupt decline" ${ }^{\text {" }}$.

However, he admits "the abrupt decline", i.e. old age leading to inevitable changes, you are as if "on the edge of the roof" ". Seneca's attitude in this letter is mostly sympathetic, although he underlines that old age should not be simply endured, but also enjoyed. However, those who waste their life, waiting only for pleasure, are likely to suffer more when getting old:

"they spend life in making ready to live! <...> Old age surprises them while their minds are still childish, and they come to it unprepared and unarmed, for they have made no provision for it" ${ }^{\text {"42 }}$.

"they fight against the weakness of the body, they judge old age to be a hardship on no other score than because it puts them aside." 43

The philosopher Seneca states, "Senectus morbidus est" ("Old age is a disease"). Thus, the ideal old age in his interpretation is a healthy one with intellectual activities, because the highest value consists in the activities of the mind, i.e. when the body declines, the mind preserves its vigour. He promotes the idea of living for the others, as we mature, especially those who suffer from the decline of body and mind.

The problems of old age are discussed by another representative of ancient philosophy, Ovid, in his Metamorphoses. For him, ageing is a physiological

${ }^{38}$ Seneca. Letters from a Stoic. Epistulae Morales ad Lucilium. London: Penguin Books Ltd., 1969. Letter 26.

${ }^{39}$ Ibid.

${ }^{40}$ Ibid.

${ }^{41}$ Ibid. Letter 12.

${ }^{42}$ Seneca. On the shortness of life. London: Penguin Books, 2004. P. 6.

${ }^{43}$ Ibid. P. 14. 
process which affects both men and women. The changes in the appearence are immediately visible and only magic may help to reverse them. Hermeneutic studies of Ovid's Metamorphosis assume that the narrative discourse of the elderly in the poem is characterized by three main features: selective memory, self-glorification and sententious moralism ${ }^{44}$. Ovid regards old age as the fourth stage of life, when a person is exhausted and harassed, trapped by death. The image of physical decay dominates in the novel and Ovid compares old age to severe winter, "Then aged winter comes shivering in, with tottering steps, its hair all goneor what it has turned white." He views ageing as metamorphosis, i.e. physical changes in the body: wrinkles, hair whitening, the loss of strength which he calls "trappings of age" 45 .

Medieval Europe has inherited many of their basic ideas about old age from the ancient times, although the philosophers of that period were discussing the problems of ageing concentrating on their theological aspects. This epoch presents the rise of the striking difference between the earthly and heavenly life, between the secular and the divine. Dante Aligiery, known for his The Divine Comedy, also writes about age and growing old. He is called a Neoplatonist who "looked at the universe as multiplicity that proceeded downwards from the supreme unity that existed in the mind of God"46. Dante distinguishes four ages of men which he calls Adolescence, Youth, Old Age and Decreptitude. In Dante's opinion, old age begins at forty five and usually lasts till seventy with. The old are portrayed positively in his works, being regarded as the source of wisdom. They are said to know a lot about the past and the present, understand what fairness and justice mean and practise respect in relations among themselves and other age groups (see, for example The Banquete, book 4, Ch.XXVII) ${ }^{47}$. Within the theological paradigm of the epoch, Dante views the human nature as oriented at God. Yet this process of refinement is accompanied by biological decline. Old age for Dante is the ultimate stage of virtues and maturity, followed by the age of decreptitude. Crytics consider that his spiritual and metaphysical view on physical decline means "a final ascent to God". He compares an older man to an old sailor who returns to his port, thus a noble soul "should enter the last haven with gentleness and peace" ${ }^{48}$.

The Christians believe that the world was created by God, and will also be ruined by God. Only the noble soul is immortal, living a meaningful blessed life

\footnotetext{
${ }^{44}$ Nikolopoulos A. D. Tremuloque gradu venit aegra senectus: Old Age in Ovid's “Metamorphoses” / Mnemosyne, 2003. 56 (1). 4th series. P. 59-60.

${ }^{45}$ Ibid. P. 50.

${ }^{46}$ Murphy C. F. Reflections on Old Age: A Study in Christian Humanism. Eugene, Oregon: Resource Publications, 2015. P. 9.

${ }^{47}$ Cited in Ibid. P. 10.

${ }^{48}$ Murphy C. F. Reflections on Old Age: A Study in Christian Humanism. Eugene, Oregon: Resource Publications, 2015. P. 11.
} 
leads to salvation ${ }^{49}$. In fact, in the medieval philosophy there appeares an image of an elderly transcendental older person whose highest desire is to return to its source, to God. This conception of life is a reflection of the general religious attitude of that period. With the constant fear of the hell, the elderly were reminded of the necessity to save their souls, make their last years useful for the spirit, despite their miserable decrepit bodies.

Another representative of this epoch, Petrarch, develops a number of ideas relevant even for modern thinkers, namely and the idea of apotheosis of divine creativity and maturity of old age, the vanity of human trifle aspirations, inevitability of death. Being inspired by the works of Cicero and Seneca, he writes a series of Letters of Old Age in which he discusses his philosophy in life. The passage of time is a common theme in Petrarch's works ${ }^{50}$. He understands the brevity of his life and impending old age urges him to be more careful with how he spends his time: "when the difficulties of life are pressing on me so sharply and inexorably and the cares pertaining to my literary labours make the longest life seem far too short." It is claimed in recent research, that "throughout Book VIII's eight letters, there is a continuing resonance of the Ciceronian and Senecan representation of old age as a period of dignity, serenity, wisdom, and inner freedom for a self-motivated man", they speak of the benefits of old age (Sen. VIII, 2), or the widespread and wrong belief in fortune's adversity and in opinions (Sen. VIII, 3), and the importance of friendship (Sen. VIII, 4) s1. $^{51}$

Enlish philosopher Roger Bacon studies the causes of ageing and the ways of increasing life span. Being a theologist, he admits the brevity of human life as compared to our Biblical patriarchs. He seems to be convinced that human beings could live longer if they led a different, healthful lifestyle. Bacon believes that the salvation of the Christians is related to scientific breakthroughs and in recent researches he is assumed to become famous for his advances in experimental science ${ }^{52}$.

Despite some of the positive portrayals of old age, it was commonly frightening and morbid in Middle Ages. Geoffrey Chaucer in his Canterbury Tales compares old age to a rotten fruit. He also provides a metaphorical representation of it as an empty barrel:

The day I was born a long time ago, death opened up the spigot of my life and left it on. And ever since that day the old tap has just run and run until now the barrel is practically empty ${ }^{53}$.

\footnotetext{
${ }^{49}$ Полькина Т.М. Особенности понимания феномена старости на разных этапах психологофилософского осмысления / Вестник Башкирского университета, 2012. Т. 17. № 3. С. 1409.

${ }^{50}$ Barolini T. The Self in the labyrinth of time. Rerum vulgarium fragmenta. / A Critical Guide to the Complete Works. Eds. Victoria Kirkham and Armando Maggi., 2009. P. 33.

${ }^{51}$ Skenazi C. Aging Gracefully in the Renaissance.Stories of Later Life from Petrarch to Montaigne. Leiden.Boston: Brill, 2013. P. 74.

${ }^{52}$ Murphy C. F. Reflections on Old Age: A Study in Christian Humanism. Eugene, Oregon: Resource Publications, 2015. P. 13-14.

${ }^{53}$ Cited in Ibid. P. 14.
} 
Mickelangelo also contributes to Medieval Philosophy and in his poems depicts his attitude towards this stage of life. His philosophy is based on the ideas of Neoplatonism. Old age for him is characterized by the inconsistency between the form and the content. On the one hand, older people are geniuses, intellectually prominent, on the other, they are visually unattractive, even ugly. Such a realistic understanding of old age corresponds to the author's goal, since he believes that only when the material outer form is cast out, the inner wisdom is revealed. Thus, the only way for humans in their efforts to ascend to the divine, eternal life is creating masterpieces that would be inherited by future generations and promote immortal living ${ }^{54}$.

A more rational approach is seen in the works of Francis Bacon, a founder of gerontology, who analyses old age from the applied-scientific point of view. In one of his works of Youth and Age, he compares the advantages and disadvantages of these two stages and concludes that each of them has both positive and negative values. Some of the present-day philosophers claim that old age, according to Bacon, has the power of understanding, although it can be criticized for its "mediocrity of success" 55 .

In the realm of natural philosophy with an accent on the Christian world view, old age is described by Leibniz, one of the great thinkers of the seventeenth and eighteenth centuries. Leibniz assumes that "all corporeal phenomena can be derived from efficient and mechanical causes," though there may be final causes (or "higher reasons") that underlie them ${ }^{56}$. Leibniz believes that each substance has a unique series of perceptions programmed by God to play in harmony with all other substances.

The pragmatic approach to ageing is observed in Hobbes' works where he compares a person with material things that have their cost and value depending on the usefulness and demand for them in society. Accordingly, old age loses its existential content and is regarded from the purely consumerist approach. For Hobbes, those who accumulate wealth, are better prepared for old age and can provide for themselves ${ }^{57}$.

Representative of new European philosophy, Nietzsche was a gifted writer, as well as an academic who developed extraordinary insight into some of the most complex ideas. It is obvious, that the thinker differentiates between the ageing of the body and that of the mind, "Profundity of thought belongs to

54 Полькина Т.М. Особенности понимания феномена старости на разных этапах психолого-философского осмысления / Вестник Башкирского университета, 2012. Т. 17. № 3. C. 1409 .

${ }^{55}$ Murphy C. F. Reflections on Old Age: A Study in Christian Humanism. Eugene, Oregon: Resource Publications, 2015. P. 16.

${ }^{56}$ Leibniz G.W. A Specimen of Dynamics (1695). / Philosophical essays. Ed. \& Transl. by R. Ariew \& D. Garber. Indianopolis \& Cambridge: Hackett Publishing Company, 1989. P. 126.

57 Stewart D. Thomas Hobbes / The Stanford Encyclopedia of Philosophy (Spring 2019 Edition), Edward N. Zalta (ed.). Available online at https://plato.stanford.edu/archives/ spr2019/entries/hobbes/>. 
youth, clarity of thought to old age" ${ }^{\text {58 }}$. What he fears most is mediocrity. His ideal is Übermensch "overman", while the opposite of the Übermensch is called der letzte Mensch, "the last man.” Strong people have no fear of old age, moreover such people are not frightened even by the prospect of inevitable death. Nietzsche experienced a number of serious health problems, therefore he believed that it is important to finish your earthly life in good time, where 'good' means before getting old ${ }^{59}$.

In Britain at the end of the eighteenth cebtury, The Rambler, an essay periodical was edited and mostly written by Samuel Johnson, in some of its issues the problems of old age and the relations between old and young are discussed (e.g., Rambler \#\#50, 69). Although Johnson denies the idea of fruitfull communication between these age groups, since he believes they are too different and share no similar hopes, he admits that such relations could be mutually rewarding, e.g. "Youth to be taught the piety of age - age to retain the honour of youth". Furthermore, he reminds that the old and the young should be tolerant to each other, "he is young, consider that he shall one day be old and remember when he is old that he had once been young" and goes on to state that the young have to honor the wisdom of the old. Also, he provides a metaphor to describe them as two extreme opposing seasons, winter and spring, "though the contrariness of Winter and Spring can never be fully united, mutual tenderness and respect can draw the extremes of age closer together."60 Moreover, interesting theses on retirement are observed in Rambler, where Johnson promotes the idea of voluntary retirement before you are induced to retire. Similar to Hobbes's ideas, the importance of well-being is highlighted, if you have accumulated some financial wealth and have your family's support, you will not feel neglected in old age.

The philosophy of ageing in the English-speaking world is said to be greatly influenced by S. de Beauvoir's The Coming of Age (1972), which is seen as reaction against the classical ancient studies of old age ${ }^{61}$. Beauvoir believes that later life is idealized and excessively romantisized and highlights the horrors of physical life of the elderly, their social isolation and contempt, "We must assume a reality that is certainly ourselves although it reaches us from the outside and although we cannot grasp it. There is an insoluble contradiction between the obvious clarity of the inward feeling that guarantees our unchanging quality and the objective certainty of our transformation. All we can do is to waver form the one to the other, never managing to hold them both

${ }^{58}$ Nietzsche F. AZQuotes.com. Wind and Fly LTD, 2019.

${ }^{59}$ Ницше Ф. Так говорил Заратустра. [пер. с нем. Ю. Антоновского]. СПб.: Издательская группа «Азбука-классика», 2010. С. 74.

${ }^{60}$ Cited in: Murphy C. F. Reflections on Old Age: A Study in Christian Humanism. Eugene, Oregon: Resource Publications, 2015. P. 17.

${ }^{61}$ Nikolopoulos A. D. Tremuloque gradu venit aegra senectus: Old Age in Ovid's "Metamorphoses" / Mnemosyne, 2003. 56 (1). 4th series. P. 49. 
firmly together" ${ }^{\text {"2 }}$. The Coming of Age consists of two parts: outsiders' look at the elderly and the elderly's own inner understanding of old age. The first part presents analysis from biology, gerontology, anthropology, history and sociology which observe the elderly as "from the outside", whereas in the second part Beauvoir shows how she experiences old age as "from the inside", based on her own experience of herself and her family.

Beauvoir discusses ageing also from the viewpoint of time, "Age changes our relationship with time: as the years go by our future shortens, while our past grows heavier. The aged man may be defined as an individual with a long existence behind him, and before him a very limited expectation of life" ${ }^{\text {"63 }}$.

\section{Reconceptualization of ageing in the discourse of modern philosophy}

Present-day philosophers discuss old age and the aged, as well as interpret ageing processes. They present the analyses of concepts important for our understanding of this stage of life, the problematic aspects of human longevity. These narratives can be used as sources to disclose the main conceptual features of OLD AGE concept. The material for this study presents discourse fragments randomly selected from Jan Baars's Philosophy of Aging, Time, and Finitude and Kevin Aho's The contraction of time and existential awakening: a phenomenology of authentic ageing.

Research results show that OLD AGE in the discourse of philosophy is verbalized as [a period/state when one is old] by means of the key lexeme old age, together with its synonymic nominative units: age, oldness, elderliness, years, senility; a higher age, later years, the passing of time, seasons of life.

Depending on the perspective, present-day thinkers accompany the concept's key lexeme (or its synonyms) with the markers, i.e., words, word combinations or contexts with different notional and figurative-emotive content which provide the multifaceted description of old age: e.g., human/social/authentic/chronological/adult aging, the neglect/story/narrative/ image/slowness of aging, social aging, age theorists/identity/cohort, etc.

The analysis shows that old age is perceived as: a) transforming, liberating power which grants access to a new understanding of the present: old age is sharpening my awareness; the breakdown of the body can pull us out of our harried restlessness, slowing us down and granting us access to the poignancy of the present moment; b) a new identity, socially created: aging can illuminate the value of ontological flexibility, of letting-go of the ego and freeing ourselves from identities that are no longer livable; old age as an experience of fragmentation or splitting off from one's former self; old age is socially created, sustained and elaborated; c) noncompliance, limiting the activity and

${ }^{62}$ Beauvoir Simone de. The Coming of Age. 1970 / Trans. Patrick O’Brian. New York: W.W. Norton, 1996. P. 290.

${ }^{63}$ Ibid. P. 361. 
possibilities, leading to isolation of the elderly: senility is just a convenient tag on which to hang non-conformity; aging as the inevitable narrowing and tightening of this horizon (of existential possibilities).

A highly debated issue in philosophy is delimiting old age, defining the time when one becomes old. As it is stated in the present-day research, "One of the main paradoxes we are confronted with is that all human beings are constantly aging, but at a certain moment in life one is labeled aged or older (older than whom?) and life beyond that point is labeled aging"64. The answer to this question does not seem so simple. Gerontological studies usually begin by defining their population in terms of chronological age. Old age is commonly founded on the number of years lived. However, it seems true that "individuals are transformed into an "aging," "aged," or "older" body at a particular chronological age without any evidence that important changes are taking place at that age, apart from sudden cultural relocation. This relocation into the category of the "aged" or "older" may take place at the age of 40 years when the stigma of the "older worker" begins to hit, especially for one who has become unemployed" 65 . This example with a high deegre of possibility indicates the fall of age as an indicator of ageing which means that the definitions of old age are no longer based only on chronological age, rather on social criteria, such as (un)employment. Also, in redefining old age material well-being is regarded as an important factor: e.g., "a class of poor persons may be considered old at 40, while a class of wealthy at 70." Thus, philosophers come to the conclusion that societies also influence the perception of ageing, because, "the rates at which one ages, how one ages, and the ways in the ageing $<\ldots>$ are at least partly socially generated". It is commonly agreed that old age is a historically sensitive issue and social changes in this field in the course of the last century are quite obvious. Advances in science and medicine encouraged the increase in the life expectancy, accordingly " 50 is the new 40, 60 is the new 50".

An important part in the nominative field of the concept OLD AGE is represented by the synonymic anthropological group of nominative units denoting [the person who is old]: aged, the aged person, aging people, aging person, the elderly, elderly adults, elderly person, geezer, happy pensioner, a nursing home resident, old people, old person, older person, older individuals, old timer, people getting on in years, person who has lived many years, 60-year olds, 70-year olds.

The examples above may help to define main properties of the ageing identity as verbalized by these units. The results show that this conceptualization seems to be determined by social factors or/and institutialization of old age

${ }^{64}$ Baars J. Philosophy of Aging, Time, and Finitude. / A Guide to Humanistic Studies in Aging. Eds. T.R. Cole, R. Ray \& R. Kastenbaum. Baltimore: Johns Hopkins University Press, 2010. P. 4-6.

${ }^{65}$ Ibid. 
(elderly person, aged person, the aged, aging people, aging person, old people, old person, older person, older individuals, elderly adults, the elderly, a nursing home resident, pensioner), chronological indicators denoting the actual number of years or longevity (60-year olds, 70-year olds, people getting on in years, person who has lived many years), as well as stereotypes and prejudiced attitudes (geezer, old timer). The most common perception of older adults is that they have lived a long life, are retired/have finished their working lives and receive pensions from the government. However, this perception seems to be greatly influenced by negative social stereotypes emphasizing that "the elderly are, among other things, socially and technologically incompetent; have diminished cognitive functioning; are no longer physically desirable or sexually active; and are lonely and depressed" ". Moreover, they are said to be outdated, having no prospects in future, e.g. "people over forty-five basically die in terms of new ideas" 67 .

Another deeply rooted stereotype, influenced by destructive ageist culture, is the prejudiced attitude towards the elderly who are assumed to differ so much from the rest of the population, that they are seen as abnormal, "The expressions aged and aging are without any justification understood as references to a special and abnormal group" ${ }^{68}$.

Within this approach getting older means becoming different, not only from the younger population, but also from the fomer self, which may result in the loss of one's personhood, "the view that the elderly are somehow separate and discontinuous with their younger or middle-aged self" 69 .

The common markers of the older people are expressed by negative evaluative adjectives: inactive, silent, submissive, non-functional, nonproductive, incompetent, burdensome, lonely, depressed, etc. All these features of OLD AGE, in general, and the elderly, in particular, are seen from the outside, by society. When seen from the inside, they commonly result in "decreased self-esteem, self-efficacy, and overall life satisfaction" of the elderly themselves ${ }^{70}$.

The main themes that may be important for understanding the concept OLD AGE in the discourse of philosophy are grouped as to their connotations into negative evaluative, including the feelings of sadness and despair, the concept of nostalgia, loneliness and isolation, losses, the invisibility of the elderly by societies, limits of their agency, the issues of autonomy and personhood in later

${ }^{66}$ Aho K. The contraction of time and existential awakening: a phenomenology of authentic ageing. P. 2.

${ }^{67}$ Ibid.

${ }^{68}$ Baars J. Philosophy of Aging, Time, and Finitude. / A Guide to Humanistic Studies in Aging. Eds. T.R. Cole, R. Ray \& R. Kastenbaum. Baltimore: Johns Hopkins University Press, 2010. P. 4-6.

${ }^{69}$ Aho K. The contraction of time and existential awakening: a phenomenology of authentic ageing. P. 17.

${ }^{70}$ Ibid. P. 2. 
life, and positive, conceptualizing the idea of liberation/freedom, perceiving ageing as transformation or the age of new opportunities.

The process of ageing is seen as a series of losses. Firstly, the elderly are assumed to be greatly influenced by personal losses, such as the loss of beloved ones, at a loss where ageing is concerned.

Furthermore, it might be the loss of personhood, the loss of one's identity: e.g., as we get older, our identities are under continual threat; unable to inhabit or perform our identities in the same way; the experience of fragmentation or splitting off from one's former self; the loss of one's former self; no longer regarded as a person we used to be; dehumanize the elderly; different elderly; less human; low in value; fail to acknowledge them as people; decreased selfesteem; losing control of one's life.

Old age is also assumed to cause the loss of autonomy and independence: moving into assisted living.

The institutialization of ageing in the course of the last century has resulted in the isolation of the elderly, they are seen as "impediments to progress"71, socially abandoned, burdensome and lonely. The following fragments clearly highlight these features of the concept OLD AGE: exclusion from the most central domains of life; stay away from the places where elderly congregate; restricted social networks; withdrawal from society; a nursing home resident; keep them out of workplace.

The elderly are potrayed as ignored, not fitting in the demands of modern societies with uncertain future: the horizons of possibilities contract; the insecurity of the future; a destructive form of presence in the past; cannot keep up with the speed of modern life; contracting, narrowing possibilities.

In our youth-obsessed societies, the process of ageing is commonly believed to be medicalized, as a result, old age is viewed as deterioration or physical and mental decline: the inescapable movement toward disability and death, changing biological processes, the devastation, the haunting prospects of dementia, old age as impairment, failing organs, failing health, brittle bones, centrality of health concerns in self-definition, diminished cognitive functioning, ageing is a meaningless and inescapable process of decline.

Furthermore, ageing is regarded as deviation from the norm, anomaly, abnormal process: ageing is not "normal" (social norm is young and healthy); ageing is not a "natural" process; ageing and aged $<\ldots>$ abnormal groups.

The emotional sphere characterization is predominantly negative, expressed as a state of being old with the feelings of regret, resentment, bitterness, sadness, shame, vulnerability etc.: e.g., sunlight gives $<_{\ldots} . .>$ joy no more; the poignancy of the present moment; a void stillness that can be terrifying; lonely and painful death; depressive feeling of being trapped.

\footnotetext{
${ }^{71}$ Murphy C. F. Reflections on Old Age: A Study in Christian Humanism. Eugene, Oregon: Resource Publications, 2015. P. XI.
} 
The conceptual features which provide positive evaluation of OLD AGE are less representative. They are principally associated with the idea of liberation, the notions of freedom and transformation.

In conceptualization of the elderly, the ancient idea of transformation is also observable: "not born an elderly, but become an elderly", thus ageing is seen not as a static notion, but is presented dynamically. Moreover, this transformation might be viewed as opening new horizons for the elderly, for their further development: opportunity for personal and spiritual growth by opening aspects of life we fail to see when young; transformed outlook, a more profound understanding of reality; existential awakening, sharpening awareness; we become more selective in our social commitment, become aware of fragility and preciousness of the present moment, expectant decisiveness to be patient and courage to go slowly.

Old age is also viewed as a qualitatively new stage, with new oppurtunities, aspirations, the age of wisdom and maturity: a possibility for wisdom and deep meaning, the reservoirs of depth and richness; a glorious thing; a signal of rebirth; opportunity for personal and spiritual growth, wisdom and meaning; growth in experience and competence; the perfectly insured life of a happy pensioner.

The idea of liberation is not new in philosophy, it can be seen throughout the centuries, beginning with the works by Plato, where he develops the concept of freedom in connection with aspects of metaphysics, epistemology and ethics. Ageing is assumed to free the person from their previous worries and concerns: liberation from illusion of our permanence; to be free and flexible with our selfinterpretations; being unlocked; freedom and letting go; liberating function; free from trivial concerns; old age as a potential site for liberation.

Present day thinkers, also continuing Plato's tradition of highly praised and respectful old age, consider it to be a unique period: unique contributive role, age reached by few.

\section{CONCLUSIONS}

Significantly increased life-expectancy over the past century has encouraged series of approaches to the study of the nature and problems of old age and ageing in different contexts. My particular interest in this paper is philosophical interpretation and perceptions of senescence, and the ways the elderly and old age are conceptualized in discourse. The adopted in this work approach gives insight into the problems related to OLD AGE as it is percieved by philosophers in different time periods and helps to trace main tendencies in its conceptualization. Our present-day perceptions of ageing reflect our cultural and historical background and seem to be based on social conventions, prejudices and fears. However, the research into this area has had a long history. Philosophers have been working on the problems of old age for thousands of years, trying to answer the same metaphysical questions that are holding the attention of reserchers today. 
This paper begins with the survey considering the evolution of views on old age in the history of philosophy. The analysis has shown that, for ancient thinkers, old age presented a disputable question, being the object of fear or intolerance, on the one hand, and respect, maturity and wisdom, on the other. Despite a predominantly negative attitude towards old age, classical philosophers advocated a relatively optimistic view of the elderly as senior advisers and valued for their wisdom citizens. During the Middle Ages, there appeared a new theological interpretation of old age, with the image of a transcendental older person with the declining body, but immortal soul, whose main desire is salvation and a final ascent to the divine, eternal life. The modern epoch supports a rational pragmatic attitude towards the elderly. Although life expectancy is increasing, older people are commonly seen as a burden for society, which has led to their social isolation and less inclusion in the community activities.

In the second part, the paper focuses on rethinking old age in the presentday society and and the analysis of approaches to the definition of this human stage of life. The data suggest that the definitions of old age are no longer based only on chronological age, but also on social criteria, such as (un)employment and/or material well-being and wealth. These basic findings are consistent with the research showing that the conceptualization of the ageing identity also proves to be determined by the institutialization of old age, social factors, stereotypes and prejudiced attitudes.

Overall, the most common themes, relevant for understanding the conceptualization of OLD AGE in the discourse of philosophy, have been outlined. Results indicate that the textual plane is predominantly negative with the perception of ageing as decline, the age of loneliness and limited possibilities, highlighting the loss of autonomy and personhood, the state of sadness and despair. Positive conceptualization is observed only in an inconsiderable number of discourse fragments, portraying ageing as transformation, liberation or the age with new opportunities.

Future research is needed to validate these conclusions and explore the conceptualization of OLD AGE in other types of discourse.

\section{SUMMARY}

This chapter aims to examine the concept of OLD AGE in the discourse of philosophy. Firstly, it gives insight into the ways in which this stage of human life is featured across the ages in the history of philosophy. Accordingly, the survey of ideas about old age and the elderly by ancient philosophers, as well as modern thinkers, is conducted to trace the transformation of their approaches to interpreting senescing processes. Furthermore, the paper discusses main themes of OLD AGE conceptualization in the present-day English discourse of philosophy in order to define its main conceptual features. Ageing and old age are seen as complex life stages, conceptualized as liberation or freedom, 
the period of transformation with new opportunities, the rule of wisdom, on the one hand, and sadness and despair, loneliness and isolation, the losses of autonomy and identity, the invisibility of the elderly by societies, narrowing the limits of their agency, on the other. The findings of this research might provide further implications for critical discourse analysis of the concept OLD AGE in other types of discourse.

\section{REFERENCES}

1. Aho K. The contraction of time and existential awakening: a phenomenology of authentic ageing. Available at http://fgcu.academia.edu.

2. Angel J. L. The length of life in ancient Greece. / Gerontology, 1946. 18. P. 18-24.

3. Aristotle. On Longevity and Shortness of Life. / Translated by G. R. T. Ross. Available online at http://classics.mit.edu//Aristotle/longev_short.html.

4. Audrey A. Aging in classical philosophy. / The Palgrave Handbook of the Philosophy of Aging. Hrsg. Geoffrey Scarre. London: Palgrave Macmillan, 2016. P. 115-134.

5. Baars J. Philosophy of Aging, Time, and Finitude. / A Guide to Humanistic Studies in Aging. Eds. T.R. Cole, R. Ray \& R. Kastenbaum. Baltimore: Johns Hopkins University Press, 2010. P. 105-120.

6. Baars J. Aging and the Art of Living. Baltimore: Johns Hopkins University Press, 2012. 304 p.

7. Barolini T. The Self in the labyrinth of time. Rerum vulgarium fragmenta. / A Critical Guide to the Complete Works. Eds. Victoria Kirkham and Armando Maggi., 2009. P. 33-62.

8. Beauvoir Simone de. The Coming of Age. 1970. / Translated by P. O’Brian. New York: W.W. Norton, 1996.

9. Burstein S.M. and Finch C. E. Longevity examined: an ancient Greek's very modern views on ageing. A 2,000-year-old view of old age. / Nature, 23.08. 2018. Vol. 560.

10. Cicero Marcus Tullius. De Senectute (On Old Age). / Translated with an Introduction and Notes by Andrew P. Peabody. Boston: Little, Brown, and Co., 1887. Available online at https://oll.libertyfund.org/titles/543.

11. Diamandopoulos A. The ideas of Plato, Aristotle, Plutarch and Galen on the elderly. /JGG, 2017. 65. P. 325-328.

12. Leibniz G.W. A Specimen of Dynamics (1695). / Philosophical essays. Ed. \& transl. by R. Ariew \& D. Garber. Indianopolis \& Cambridge: Hackett Publishing Company, 1989. P. 117-138.

13. Murphy C. F. Reflections on Old Age: A Study in Christian Humanism. Eugene, Oregon: Resource Publications, 2015. 121 p.

14. Nietzsche F. AZQuotes.com. Wind and Fly LTD, 2019. Available online at https://www.azquotes.com/quote/538746. 
15. Nikolopoulos A. D. Tremuloque gradu venit aegra senectus: Old Age in Ovid's “Metamorphoses". / Mnemosyne, 2003. 56 (1). 4th series. P. 48-60. Available online at http://www.jstor.org/stable/4433404. P. 59.

16. Plato. Complete Works. Ed. John Cooper. Indianapolis: Hackett, 1997. $1808 \mathrm{p}$.

17. Seneca. On the shortness of life. London: Penguin Books, 2004.

18. Seneca. Letters from a Stoic. Epistulae Morales ad Lucilium. London: Penguin Books Ltd., 1969.

19. Skenazi C. Aging Gracefully in the Renaissance.Stories of Later Life from Petrarch to Montaigne. Leiden.Boston: Brill, 2013. 178 p.

20. Stewart D. Thomas Hobbes / The Stanford Encyclopedia of Philosophy (Spring 2019 Edition), Edward N. Zalta (ed.). Available online at https://plato.stanford.edu/archives/spr2019/entries/hobbes/>.

21. Whittington F.J., Cole T.R. What's the Point of Aging? Does Philosophy Make a Difference? / The Gerontologist, 2014. Vol. 54. No. 3. P. 519-521. https://doi.org/10.1093/geront/gnu025.

22. Williams M. E. Growing Old in Ancient Greece and Rome. How history helps us see ourselves as we age. 2017. Available online at https://www.psychologytoday.com/us/blog/the-art-and-science-aging-well.

23. Woodcox A. Aristotle's Theory of Aging. / Cahiers des études anciennes. LV. 2018. P. 65-78. Available online at http://journals.openedition.org/ etudesanciennes/1040.

24. Мовчан М.М. Лабіринти страху старості: проблеми і перспективи / Гуманітарний вісник ЗДІА, 2013. o 53. С. 79-90.

25. Ницше Ф. Так говорил Заратустра. [пер. с нем. Ю. Антоновского]. СПб.: Издательская группа «Азбука-классика», 2010. 352 с.

26. Полькина Т.М. Особенности понимания феномена старости на разных этапах психолого-философского осмысления / Вестник Башкирского университета, 2012. Т. 17. № 3. С. 1407-1412.

Information about the author: Holyk S. V. Candidate of Philological Sciences, Associate Professor, Head of the English Philology Department of the State University "Uzhhorod National University" 14, Universytetska str., Uzhhorod, 88000, Ukraine 